ECONOMICS

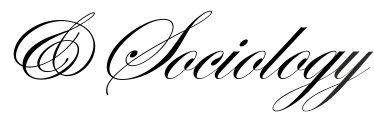

Győző Attila Szilágyi,

Óbuda University,

Doctoral School on Safety and

Security Science,

Budapest, Hungary,

E-mail:

szilagyi@strategiakutatas.bu

Received: December, 2016

1st Revision: March, 2017

Accepted: June, 2017

DOI: $10.14254 / 2071-$

789X.2017/10-3/13

\section{EXPLORATION KNOWLEDGE SHARING NETWORKS USING SOCIAL NETWORK ANALYSIS METHODS}

\begin{abstract}
Knowledge sharing within organization is one of the key factor for success. The organization, where knowledge sharing takes place faster and more efficiently, is able to adapt to changes in the market environment more successfully, and as a result, it may obtain a competitive advantage. Knowledge sharing in an organization is carried out through formal and informal human communication contacts during work. This forms a multi-level complex network whose quantitative and topological characteristics largely determine how quickly and to what extent the knowledge travels within organization. The study presents how different networks of knowledge sharing in the organization can be explored by means of network analysis methods through a case study, and which role play the properties of these networks in fast and sufficient spread of knowledge in organizations. The study also demonstrates the practical applications of our research results. Namely, on the basis of knowledge sharing educational strategies can be developed in an organization, and further, competitiveness of an organization may increase due to those strategies' application.
\end{abstract}

Keywords: knowledge sharing, social network, network theory.
JEL Classification: D82, D83, D85

\title{
Introduction
}

Organizations have to compete in a fast and frequently changing market environment taking into account the influence of new communication and marketing opportunities provided by the globalization and the Internet (Friedman, 2005). Any organization that wants to remain in competition in this turbulent market environment must consider completely new approaches. In the past, success of an organization was determined by quantity and quality of resources owned by this organization, and the efficiency of its technological and management processes (Fayol, 1949). Corresponding to this, management methods were developed so that to boost the competitiveness by regulation of management processes. Later, quality management for frequent operational procedures (Juran, 1998), project management for specific project processes (Verzuh, 2005) etc. provided methodologies to improve competitiveness meanwhile reducing the number of necessary resources and increasing the level of secure operations. There is, however, little or no advantage of knowing and applying these well-tried management methods in the post- industrial era, since those are easily 
accessible by anyone in the Internet age. The advantage does not last long for those who adapt successfully for the first time, as newer methods become widely-known and applied (Tryon, 2012). Availability of abundant resources does not provide competitive advantage either. Low-budget garage firms are able to enter the information market with a new product, as not many assets are required for such a development. In the past the value of organization was measured through material resources it owned, nowadays the core asset of any company is knowledge of its employees in the form of ideas, know-hows and skills (Handy, 2001). In today's rapidly changing market environment not the companies with larger volumes of resources may count on success, but those who are able to learn fast and are able to adapt to new knowledge faster. Acquisition and sharing of new knowledge have its influence also on operational security of organizations by their decision-making (Lazányi, 2016a). It is not enough to recognize and acquire new knowledge fast, further spread and internalization of this new knowledge must be ensured in the organization within a short period of time (Velencei \& Baracskai, 2016). Knowledge sharing is achieved through connection of people within the organization. There are formal and informal connections among people at work, and these connections forms a complex social network. According to Barabási, "while management tends to rely on the official chain of command, it is increasingly evident that the informal network, capturing who really communicates with whom, plays the most important role in the success of an organization" (Barabási, 2016).

\section{Knowledge sharing aspects}

Nowadays, the knowledge plays a key role in market competition and has become as one of the most important resources (Boisot, 1995). However, the knowledge is more than mere data or information and problem-solving is not algorithmic (Simon, 1982). Not only persons but the organizations also have the knowledge and the ability to learn. The organizational knowledge is not just sum of all individual knowledge, but rather its synergistic effects the knowledge creation, that creates original knowledge at the organizational level (Bierly et al., 2000). There is a greater emphasis on the knowledge creation from the point of view of competitiveness of organizations. Polányi pointed out, that according to knowledge capture and codification the knowledge can be formally transferable explicit or tacit knowledge (Polányi, 1966). While the explicit knowledge can be transferred by formalized methods, the tacit knowledge is inner knowledge of the individual, that can be transferred personally in practice (Ackoff, 1989).

The knowledge must be transferred to the members of the organization in order to get organizational knowledge from individual knowledge, the knowledge exchange network evolved in the organization plays an important role in this (Szeghegyi, 2011). The knowledge can be transferred directly or indirectly (Jennex, 2009). Direct knowledge transfer provides the knowledge to the members of the organization in an organized way. Further training is one of its forms, when one member of the organization who owns the knowledge, in an organized and directed way - usually orally - transfers the knowledge to the other members of the organization. The other form, when in small groups composed of co-workers at the almost same level of the hierarchy, in quality circles share the knowledge among them (Szaboszlai et al., 2014). In these quality circles not only the knowledge transfer but knowledge creation also takes place, namely the members of the quality circles create new knowledge. The third form of the knowledge creation may take place in less hierarchical and bureaucratic organizations (Handy, 1995). In this case, the knowledge is transferred in partnership, that is realized by an instructor, coach, mentor relationships between the individuals. The instructional knowledge transfer referring to knowledge transfer to solve a specific problem, and a short-term relationship is established. In the coach relation, the aim is 
to improve a long-term task, and procedures and processes relating to knowledge are transferred. In mentor relation, a long-term relationship is established, that provides help referring to walk of life or career. Another form of the direct knowledge transfer, when the organizations set up "kitchenette", where co-workers during ad hoc conversation may transfer their knowledge freely (Velencei, 2014).

The indirect knowledge transfer arises through the structural coupling. One of the direct methods of knowledge transfer is the workplace swapping. The scope of activities of the organizational member is changed targeted and directed, in the meanwhile, the individual - besides the oral knowledge sharing completes the new knowledge with own experience as well. The other indirect knowledge sharing method is the rearrangement of the scope of work. Contrary to the previous trend - when the scope of work division into smaller parts and specialization was preferred - the aim is the pull down the functional boundaries and reduce the bureaucracy. Within this framework extension and broaden the scope of work, and establishing workgroups is highlighted, the individual gets in touch with more associates from different areas, this promotes the knowledge sharing. The third knowledge sharing possibility is the socialization, not technical knowledge but a set of behaviors is exchanged. The individual is in such work environment, where others have already internalized the behaviors and norms to be learned, therefore the individual obtains behaviors from the surrounding social environment that is difficult to share formally (Nonaka \& Konno, 1988).

The knowledge transfer consists of three parts: the knowledge transmission, the knowledge absorption, and the use the knowledge. Knowing the different layers of the knowledge transfer in the human network it may be revealed which human relationships are involved in spreading the new knowledge (Velencei, 2012), the dynamics of the spread, how widely the knowledge is spread, whether the network is capable of spreading tacit knowledge. It is important to explore these characteristics of the human network because those organizations would gain a competitive advantage in the rapidly and largely changing world who are able to respond the economic, technical, biological, cultural and environmental changes quickly and in a flexible way. According to Nonaka and Takeuchi knowledge conversion theory (Nonaka \& Takeuchi, 1995) the flexibility of an organization, that is the ability how to respond to strategic challenges depends on the knowledge that the organization owns, on the other hand, it depends on how it is able to use and mobilize the knowledge (Razmerita et al., 2016). The knowledge of the human network provides the opportunity to explore the way and dynamics of the knowledge spread also in the organization knowledge sharing networks, which may increase the mobilization of the organization knowledge.

\section{Network theory aspects}

We need to apply network methods in order to reveal how the new knowledge is spread in the organization. In the 1950's two Hungarian mathematicians Erdös and Rényi started to do research on the connection between the real evolution of the graphs, but with their work, they exceeded the aim of mathematical categorization of the graph theory. Although the achievements of Erdős and Rényi are significant in the field of a random graph (Erdös \& Rényi, 1959), but they did not develop the general theory of the origin of the network (Barabási, 2002). In the network research methodology, the next milestone is the paper of Granovetter "The strength of weak ties" shows that besides the strong ties between the nodes the weak ties are also significant in an organization in the view of the cohesion of the network (Granovetter, 1973). Based on this regularity of the networks, Watts and Strogatz introduced an indicator number that is capable of examination the system of the network in their publication. (Watts \& Strogatz, 1998). Later network research proved that regularities referring to network growth that Granovetter revealed are unrelated to the - biological, social, 
economic, spatial, etc. - nature of the network. Barabási explored the laws of the dynamics of network growth as a result of his World Wide Web research. He showed that the growth of networks is directed by two laws. One of them is the growth, the other one is a growth probability based on the preferences of some nodes (Albert et al., 2000). For the first time, the distribution based on exponential function was successfully modeled that is typical for real networks as well. The dynamic approach of networks meant a break-through in the field of network research because the networks were not considered as static formation but as a dynamically growing system.

\section{Definition of the human network}

If we consider the relationships of the members of the organization as a network, the nodes are the people, the links between them the edges between the nodes, then, in fact, we have a graph that maps the relationships of the members of the organizations (Barabási, 2002). Nowadays, many terms appear in the papers dealing with human networks, their definitions are not sorted clearly, that is why I consider important to interpret the concept of human network.

People in the course of their work come in contact not only with the people but communication tools that are necessary for the work. This system is the organizational network, the human-machine and human-human contacts are the parts of it as well. In this study the latter, the human-human network in the organization that I mean the human network. According to that, we can call social network as it is called in the sociology the network among the people. In recent times, the use of this term is also not clear, because the term social network is more frequently used only for the internet based social platforms such as FaceBook, Twitter, etc. Moreover, the other characteristics of social network also that refers to the voluntary human contacts, so the members of the network are able to select contacts who they are fond of, but this is not true for the professional relationships as they can not select generally in this way. In the study, in the human network is not only the voluntary contacts but the arranged relationships as a result of the work activities are also involved. The human network is a complex network system of the members of the organization, where the arranged relationships and the voluntary relationships are also present. The so-called "organization chart" or "organogram" in the organization documents represents only a single segment of the complex structure of the human network, the power structure.

The structural relationships based on the dependency or professional hierarchy are similar parts of the human network, as the Merei relationship system based on sympathy (Mérei, 1988), occupational substitution system, or who shares superficial information, namely who gossip with whom. These different layers jointly compose the complex human network. The complexity is not equal to complicated (Lorenz, 1963). When among the elements of the network- even the given network contains a large number of elements- their connections can be described by linear relationships, this is called complicated. When there are loopbacks, loops among the elements of the network, and that is why the relationships can be described by non-linear relationships mathematically, then we speak about the network complexity (Estrada, 2011).

\section{Research goals and the examined organization}

The direct purposes of the research are the following: exploring the knowledge sharing system of a real organization in the human network; identifying the different formal and informal networks of the knowledge sharing; comparing the different knowledge sharing 
networks topologically. The further indirect purpose of the research to prove, among the experts' views connected to knowledge sharing within the organization proving the following: the organizational organigram is misleading referring to the structure of the real knowledge sharing (Harford, 2011). The traditional organization structure is not suitable for the rapid and efficient sharing of the key knowledge (Blanchard, 2010).

The most frequently used indicator is the degree in social network analysis, that shows, that the node of the network is how many times connected directly to the other nodes (Wasserman \& Faust, 1994). If we distinguish in-degree and out-degree in the controlled network. The degree and degree distribution of the network's nodes are important characteristics of a network. The latter has been one of the most important indicators since the scale-free networks were discovered. On the basis of degree distribution, we may conclude the topological characteristics of the network, resistance to the internal and external disturbance, robustness (Wang, \& Chen, 2002), the typical dynamics of the spread in the network.

The research took place in a Hungarian recruitment and job hiring company. The company operates as a Hungarian division of a foreign company in the national labor market. It has been on the Hungarian market for 20 years, has offices throughout the country and it is one of the market leaders in Hungary. It owns good quality and large quantity infrastructure resources, its employees are highly qualified and have considerable market experience. The company had 147 employees at the moment of the research, 3 persons were in a long-term absence, so 144 persons are involved in the research.

Professional diversification has defined the company's fundamental organizational structure, but as some service is done as a project, a weak matrix structure (PMBOK, 2000) is also true for the company. The power- culture is the typical company's organizational culture according to Handy typology (Handy, 1984), that is valid for the whole company. Decisions were made typically in a tree-like structure, it was in accordance with the established functional organization structure and the power structure.

Although the operational processes were regulated, audit quality management systems were used also in the company, the company's educational strategy has not lived up to expectations. As the company operates the national network, besides the professional segmentation the regional segmentation was also considered in the development of the educational plan. Although the company sent numerous employees to external training, the new knowledge did not spread widely among the members of the organization. At the same time, many of them noted, that there is an internal professional knowledge sharing, that is carried out when they ask the professionally component colleague for advice.

\section{Methodology and data}

In the course of the research two formal and one informal knowledge sharing network layers were mapped. There is a formal knowledge sharing in the social network based on dependency hierarchy as the managers share some information in this network. The professional hierarchy network is also a platform for the formal knowledge sharing. In this knowledge sharing network, the explicit knowledge is shared in the form of internal pieces of training, cooperators co-workers in a higher rank in the hierarchy (Jennex, 2008) transfer their knowledge in the form of organized training. The professional hierarchy structure differs from the power hierarchy, as the functional organization structure marginally but allows, moreover demands the cross communication relationships between the different business sectors. The communication pattern of the power structure is not appropriate to operate professional processes (Handy, 1984). In order to map the informal knowledge sharing network, we need to explore how the knowledge sharing happens in not organized form, so who shares 
generally professional information on a daily basis at work. This network is the network of the professional information, it is an informal network, where a direct knowledge sharing is carried out, but not in an organized way, but spontaneously, so the knowledge is shared in partnership (Langfred \& Rockmann, 2016), and not only the explicit but the hidden, tacit knowledge as well (Polányi, 1966). This informal network shows, that who are the reciprocitators (Jennex, 2008) in the organization, who happily share their knowledge without limits. The informal knowledge sharing is based on trust (Lazányi, 2016b). When people face professional problems that they can not solve they turn for knowledge to those who are professionally authentic. Due to their small world characteristics, the trust-based social networks are more tolerant to disorder to random failure (Caldarelli, 2007), so they are more stable than the hierarchy based decentralized networks.

Mapping the knowledge sharing networks was carried out with the help of questions according to names, person selection and close ended questions. As the questions referred to directly to work, the privacy was not involved, so the name based survey did not have legal restrictions. A web-based software was developed for the survey, the participants could enter the filling form with an individual code. The members of the organization for their answer could choose any number person from the scroll down menu. In order to map this dependency hierarchy network, the following question was applied "Who is your direct superior in the organization?" To survey the expert instruction network the following question belonged to "Who can give you professional instructions?" In this case, a control question was applied also "Who can you give professional instructions?" The voluntary knowledge sharing network was surveyed by the following question: "Who does regularly share his/her own professional experiences with you? " The control question was: "With whom do you regularly share your own professional experiences?" The aim of the control question is to reduce the possible accidental or deliberate distortions. Adjacency matrices were set up from the answers to the questions (Caldarelli, 2007). In the rows of the adjacency matrices the members of the organization stand $(n)$ and the value of the cells $\left(a_{i j}\right)$ are 0 or 1 . In the case if the person who stands in the row of adjacency matrix sign an other person the value of the cell is 1 , otherwise 0 . Adjacency matrix A that belongs to the given question was built up this way and this matrix maps the system of the informal connections (1).

$$
\begin{aligned}
& A:=\left(a_{i j}\right)_{n \times n} \quad i=1,2, \ldots, n \quad j=1,2, \ldots, n \quad n=\text { numbers of persons } \\
& a_{i j}=\left\{\begin{array}{l}
0 \text { if the respondents person } i \text { did not signthe person } j \\
1 \text { if the respondents person } i \text { signed the person } j
\end{array}\right.
\end{aligned}
$$

The resulting adjacency matrix forms a directed graph therefore the direction of edges must be inverted hence the adjacency matrix $A$ has to be transposed.

$$
A \rightarrow A^{T}
$$

The directions of the edges of control question are identical to the knowledge spreading. Let the $A_{C}$ matrix be the matrix that was made from the control question. Let us create the matrix $A_{G}$ that is the summarized matrix of the $A$ and $A^{T}$ matrices (3). It will be the nearly real adjacency matrix of the knowledge sharing network. Hence these matrices are rectangular matrices, and the members of the organization are also in the rows and the columns, an algebraic calculation can be done. 


$$
A_{G}=A^{T}+A_{C}
$$

The knowledge sharing networks were drawn and analyzed based on this $A_{G}$ matrix by network drawing and analyzing software. On the qualitative analysis the degree-centrality and the degree distribution in the different knowledge sharing networks were examined. The degree $(k)$ is the number of the connections between the given node and the other nodes in the network. In the directed networks the number of the edges $(L)$ equals the amount of the indegree and the out-degree of the nodes (4).

$$
L=\sum_{i=1}^{n} k_{i}^{i n}=\sum_{i=1}^{n} k_{i}^{\text {out }}
$$

The degree-centrality $C_{j}$ shows that the degree of a node $j$ how bears the highest degree of the network (5). In the directed networks the in-degree and the out-degree of a given node would be different. Therefore the out-degree centrality has to be used for the modeling of knowledge spreading in the knowledge sharing networks.

$$
C_{j}^{\text {out }}=\frac{k_{j}^{\text {out }}}{\max k_{i}^{\text {out }}}
$$

The topology attributions of the networks can be concluded from the degree distribution (Barabási, 2016). The degree distribution $p_{k}$ gives the probability that the degree of a random taken node in the network is exactly $k$. Because the $p_{k}$ are probability values the sum of them is $1(6)$.

$$
\sum_{k=1}^{\infty} p_{k}=1
$$

In a network that consists of $\mathrm{n}$ pieces of nodes the normalized values give the $p_{k}$ degree distribution where $N_{k}$ is the number of the nodes that have $k$ degrees (7). Drawing the results of the whole network on a histogram the specific degree distribution of the network will be received.

$$
p_{k}=\frac{N_{k}}{n}
$$

The degree-centrality is one of the most preferred indicators in the network analysis. The most important people of the voluntary knowledge sharing were explored by the help of this indicator. The degree-distribution is a very important indicator because the process of $p_{k}$ heavily determines the spreading specifics and the robustness of the network (Barabási, 2016). Accordingly the topology specifics of the network were concluded on the grounds of the degree distribution.

\section{Network topology results}

The topological analyses have shown that the dependency network is a decentralized 
entirely tree-like structure network (Mayeda, 1972) with five hierarchies (Figure 1a). The result is in accordance with the structure of the examined organization that is in the Rules of Procedures. Typically strategic information and manager instructions relating to the operation is shared in this knowledge sharing network. The topological characteristics of the network are appropriate for such knowledge sharing, as maximum 5 steps necessary to reach the information to all members of the organization. The expert hierarchy based network does not have the tree-like structure, cross-connections appear between the links (Figure $1 b$ ). The result is in accordance with the generally typical functional organization structure (Handy, 1993). Besides the functional organization segmentation interconnections appear that are indispensable for the operation. There were $20 \%$ more links between associates than in the dependency network in the examined organization.

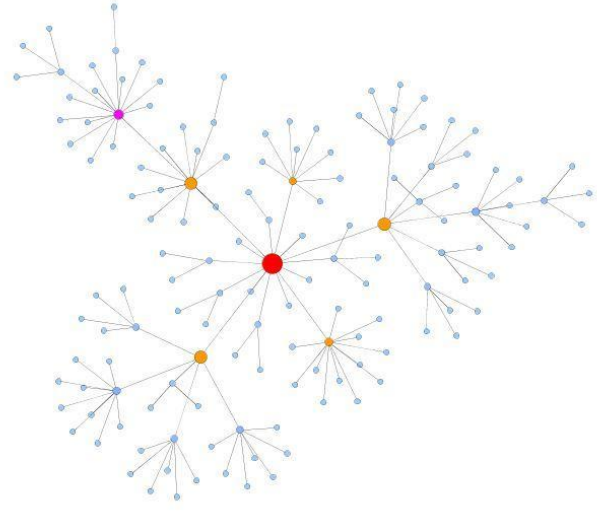

a)

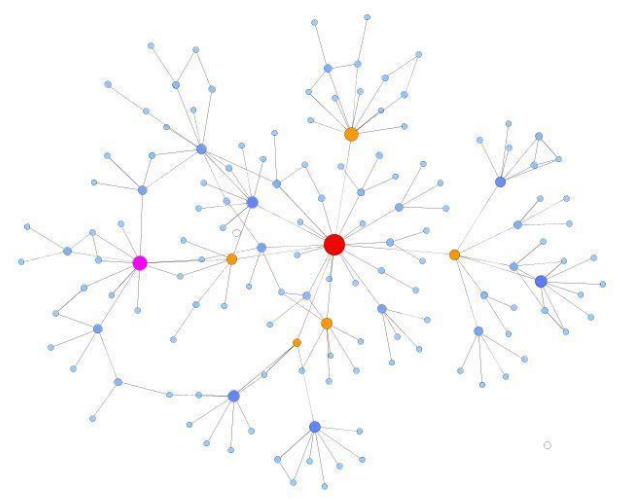

b)

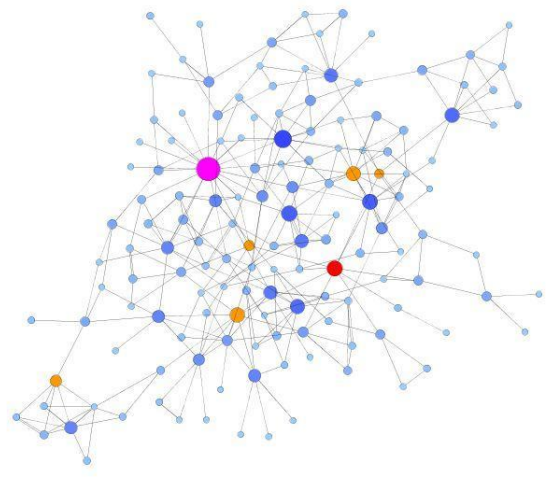

c)

a) Dependency network; b) Professional instruction network; c) Professional information network

(In the Figure the CEO is shown in red color, and the Regional Managers shown in yellow color. The sizes of the nodes are proportional to the degree number centrality value in the given network).

Figure 1. The various knowledge sharing networks in the examined organization

In the Figure 1 the CEO is shown in red color, the Regional Managers are shown in yellow color, and the person who shares the knowledge voluntary among the members of the organization is shown in purple color. The knowledge sharing net based on the voluntary basis is shown in Figure 1c. It is clearly visible, this is totally different from the dependency and also the professional hierarchy based network and it is not typical small-world type (Newman et al., 2006), rather random-network type (Figure 2). The diameter of the informal professional network (distance between the two furthest edges of the network) presents a value of 7 beside the average value of 2,49 which also suggests the random-network characteristic. Both of these values should be nearly the same in a small-world topology 
network (Newman and Watts, 1999). There are three times more relationships in this network than in the dependency, and there are twice more than in the professional hierarchy network. In the figure, the size of the hub representing certain persons is proportional to their central role, namely their centrality.

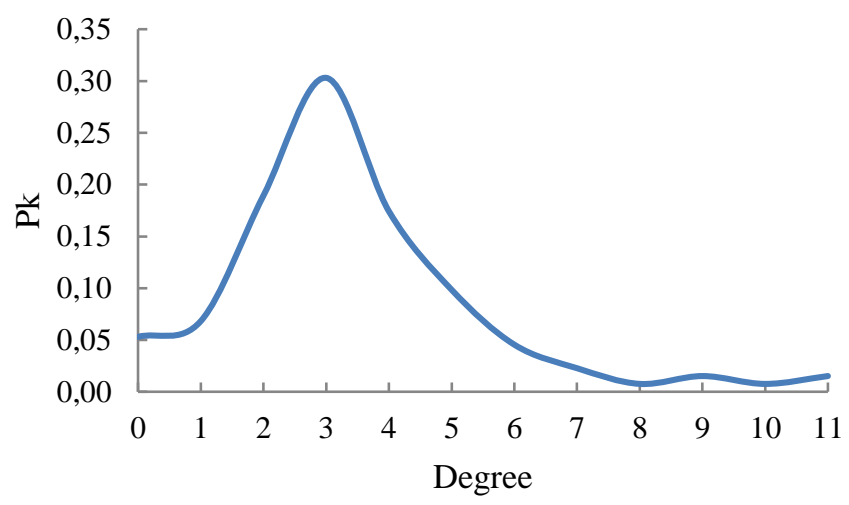

Figure 2. The degree distribution of voluntary knowledge sharing network

The Table 1 includes the marked people, degree numbers, centrality indicators of central roles played in different networks. The biggest size hub has value 1.00 the others get smaller values compared with that in the network. In the table "A" is the CEO, "B", "C", "D", "E", and "F" are the Department Managers, "G" is the associate, who typically shares the knowledge voluntarily. In fact, this person contributes to transfer tacit knowledge to explicit to the greatest extent. He is not a senior manager, but a middle manager, in the second rank of the dependency hierarchy.

Table 1. Degree centrality of certain people measured in different knowledge sharing networks

\begin{tabular}{lccccccc}
\hline & $\mathrm{A}$ & $\mathrm{B}$ & $\mathrm{C}$ & $\mathrm{D}$ & $\mathrm{E}$ & $\mathrm{F}$ & $\mathrm{G}$ \\
\hline Dependency network & $\mathbf{1 . 0 0}$ & 0.50 & 0.20 & 0.45 & 0.48 & 0.13 & 0.29 \\
\hline Expert instruction network & $\mathbf{1 . 0 0}$ & 0.30 & 0.50 & 0.30 & 0.15 & 0.35 & $\mathbf{0 . 5 5}$ \\
\hline Voluntary knowledge sharing network & 0.53 & 0.47 & 0.47 & 0.24 & 0.18 & 0.29 & $\mathbf{1 . 0 0}$ \\
\hline
\end{tabular}

As Figure 1c shows, in the voluntary knowledge sharing network, besides "G" marked in purple color there are more people hold high degree centrality indicator, who are less central in the professional hierarchy network than the Regional Managers. They are the "knowledge brokers" of the organization (Velencei, 2012). It is a noteworthy result, that "G" has higher centrality value $\left(\mathrm{C}_{\mathrm{d}}=0.55\right)$ in the professional instruction network than any other Regional Managers. Apparently, this is a contradictory result to the formal expert hierarchy, as "G" does not have many subordinates formally in the organization. Though his voluntary knowledge sharing role results that he is considered professionally superior by people who are not their subordinates in the formal professional hierarchy. This result confirms Mintzberg opinion, as middle managers play the key role in the knowledge transfer because they synthesizing the tacit knowledge of both experts and senior managers and build in new products and technologies (Mintzberg, 1998).

If we consider the professional relationships of the members of the organizations as a single professional knowledge sharing network, that has formal and informal network layers, the question arises, whether it is possible that the expert knowledge sharing network has 
fundamentally two different structures within the organization. Hence the human network is a complex network, that has more network layers, and they act parallel, the existence of two different knowledge sharing networks does not necessarily cause a problem in the practice in the organization. The almost tree-like structure of the professional hierarchy based knowledge sharing network is capable of sharing explicit knowledge very sufficiently. It is possible to transfer knowledge to a large number of people in the framework of internal training, using formal technical terms.

However, the direct explicit knowledge sharing ensures only the first element of the three elements of the knowledge sharing, the transmission of knowledge. The other two parts the absorption of knowledge and the use of knowledge depend on the trust towards the person who gave the knowledge (Lazányi, 2016b). In the course of the knowledge sharing in the hierarchy based network there is transaction participation by the members of the organization, if the knowledge sharing based on professional hierarchy happens inefficiently, in fact, the company pays the price for the risk due to the mistrust of the human relations. In the contrary when the knowledge sharing takes place in the voluntary knowledge sharing network, the participants involved voluntarily, and all the three elements of knowledge sharingtransmission, absorption and use- is established. As both knowledge sharing networks represent and operate in the organizations, the nature of the given organization's knowledge sharing is determined by the proportion transaction and transformation participation.

A similarity test was also performed on the voluntary knowledge sharing network. The aim of the test was to show how much the answers given to the question "Who does regularly share his/her own professional experiences with you?" differ from the answers given to the control question "With whom do you regularly share your own professional experiences?" The first question specifies the own knowledge sharing activity of the person, while the control question shows the others opinions about the person. Jaccard's similarity test was employed to the examination. The Jaccard coefficient measures the similarity of $A$ and $B$ data sets in such way that it compares the same elements of the two data sets with the total number of the elements of both data sets. (8)

$$
\begin{gathered}
J(A, B)=\frac{|A \cap B|}{|A \bigcup B|} \\
0 \leq J(A, B) \leq 1
\end{gathered}
$$

In that case data set $A$ is the adjacency matrix which belongs to the question "Who does regularly share his/her own professional experiences with you? " in turn $B$ is the adjacency matrix which belongs to the control question "With whom do you regularly share your own professional experiences?" Adjacency matrix belonging to control question $B$ has to be transposed to determine the Jaccard coefficient. This is necessary because the direction of the answers to the control question has to be reversed to make the direction of the knowledge sharing identical in both networks. The similarity test showed a value of $J=0,36$ in the case of the two questions referring to the voluntary knowledge sharing network. From the 383 knowledge sharing connections, which were appointed in the two questions referring to the voluntary knowledge sharing, only 137 were the same. It is apparent from this, that in the examined organisation the opinions of people about yourself and their colleagues referring the voluntary knowledge sharing are significantly different. This suggests that the image of people about the real realization of knowledge sharing is subjective. What the knowing sharing person feels like real knowledge sharing it may not be a relevant knowledge for the recipient or he/she does not feel it a real knowledge sharing. Clarifying this matter could be the aim of further researches. 


\section{Conclusions}

The research confirms that it is possible to map the different knowledge sharing networks in the organization by network research methodology. These networks are network layers of the complex human network and the knowledge sharing takes place here. Topologically the formal and informal knowledge sharing networks are different and the central role of certain persons may be different as well in the view of knowledge sharing. The topological characteristics of the different knowledge sharing networks determine which network is able to transfer which knowledge. The explicit knowledge sharing takes place in the professional hierarchy based network, while the tacit knowledge sharing takes place in the voluntary knowledge sharing network. On the basis of the topological differences between the formal and informal knowledge sharing networks, the professional relationship of trust can be concluded among the members of the organization. Given people's central role may be different in different knowledge sharing networks, the knowledge of this various training strategies can be developed in the organization. The research also highlighted that the opinion of the person about his/her own knowing sharing function could be different from the other's opinion about his/her knowing sharing role. The research revealed the organization leaders should know the characteristics of the knowledge sharing network in the future organization as it will become increasingly important because of the speed and degree of the different kind of knowledge sharing influences the competitiveness of the organization.

\section{Acknowledgement}

Thank goes to the Managing Director of the research participant company for giving the opportunity and for providing all the conditions for carrying out the research. His constructive attitude greatly contributed to the successful research. Thank goes also to all the employees of the company for taking part voluntary in the mapping of the human network. Unfortunately it is not possible to thanks to everyone by name because the condition of the company to the publishing of results were the complete anonymity of the publication because of the market competition of the examined company. It is also wished to thank to my friend Mr. Peter Szegöfi for preparing the web application for the survey, his software assured the response surface and the export of data.

\section{References}

Ackoff, R. L. (1989). From Data to Wisdom. Journal of Applies Systems Analysis, 16, 3-9.

Albert, R., Jeong, H., Barabási, A. L. (2000). Error and Attack Tolerance of Complex Networks. Nature, 406, 378-381.

Barabási, A. L. Albert, R., Jeong, H., Bianconi, G. (2000). Power-law distribution of the world wide web. Science, 287(5461), 2115.

Barabási, A. L. (2002). Linked, The New Science of Network. Cambridge, Perseus Publishing.

Barabási, A. L. (2016). Network Science. Boston, Northeastern University.

Bierly, B. E., Kessler, E. H, Christensen, E. W. (2000). Organizational learning, knowledge and wisdom. Journal of Organizational Change Management, 13(6), 595-618.

Blanchard, K. (2010). Leading at a Higher Level. New Jersey, Blanchard Management Corporation.

Boisot, M. (1995). Information Space. A Framework for Learning in Organizations, Institutions and Culture. London, Routledge.

Caldarelli, G. (2007). Scale-Free Networks, Complex Webs in Nature and Technology. Oxford, Oxford University Press. 
Erdős, P., Rényi, A. (1959). On random graphs I. Publicationes Mathematica. Debrecen, 6, 290-297.

Estrada, E. (2011). The Structure of Complex Networks. New York, Oxford University Press.

Fayol, H. (1949). General and Industrial Management. Pitman, London, Reprint 2013 by Martino Fine Books, Las Vegas USA.

Friedman, T. L. (2005). The World is Flat. A Brief History of the Twenty-First Century. Straus and Giroux, New York.

Granovetter, M. S. (1973). The Strength of Weak Ties. American Journal of Sociology, 78(6), 1360-1380.

Handy, C. (1995). The Empty Raincoat. New York, Arrow Books Limited.

Handy, C. (2001). The Elephant and the Flea. Looking Backward to the Future. London, Hutchinson.

Handy, C. B. (1984). Understanding Organizations. London, Penguin.

Harford, T. (2011). Adapt: Why Success Always Stars with Failure. New York, Farra, Strauss and Giroux.

Jennex, M. E. (2008). Current Issues in Knowledge Management. Information Science Reference, New York, Hersey.

Jennex, M. E. (2009). Knowledge Management, Organizational Memory, and Transfer Behavior: Global Approaches and Advancements. New York, Hershey.

Juran, J. M. (1998). Juran's Quality Book. New York, McGraw-Hill.

Langfred, C. W., Rockmann, K. W. (2016). The Push and Pull of Autonomy: The Tension Between Individual Autonomy and Organizational Control in Knowledge Work. Group \& Organization Management, 41(5), 629-657.

Lazányi, K. (2016a). A biztonsági kultúra szerepe a vezetői döntések támogatásában. Taylor: Gazdálkodás- és Szervezéstudományi Folyóirat: a Virtuális Intézet Közép-Európa Kutatására Közleményei, 8(1), 143-150.

Lazányi, K. (2016b). Who do You Trust? - Safety Aspect of Interpersonal Trust among Young Adults with Work Experience. In: Szakál Anikó (Ed.). Proceedings of thellth IEEE International Symposium on Applied Computational Intelligence and Informatics, SACI 2016, 412.

Lorenz, E. N. (1963). Deterministic, Nonperiodic Flow. Journal of the Atmospheric Sciences, 20, 130-141.

Mayeda, W. (1972). Graph Theory. New Jersey, John Wiley \& Sons Inc.

Mérei, F. (1988). Közösségek rejtett hálózata. Budapest, Tömegkommunikációs Kutatóközpont.

Mintzberg, H., Ahlstrand, B., Lampel, J. (1998). Strategy Safari. A guided tour through the wilds of strategic management. New York, The Free Press.

Newman, M., Barabási, A. L., Watts, D. J. (2006). The Structure and Dynamics of Networks. New Jersey, Princeton University Press.

Newman, M. E. J., Watts, D. J. (1999). Renormalization group analysis of the small-world network model. Physics Letter A., 263(4-6), 341-346.

Nonaka, I., Konno, N. (1998). The Concept of "Ba": Building a Foundation for Knowledge Creation. California, California Management Review, 40(3), 40-54.

Nonaka, I., Takeuchi, H. (1995). The Knowledge-Creating Company. New York, Oxford University Press.

PMBOK Guide (2000). A Guide to the Project Management Body for Knowledge. Pennsylvania, USA, Project Management Institute, 22.

Polányi, M. (1966). The Tacit Dimension. London, Routledge \& Kegan. 
Razmerita, L., Kirchner, K., Nielsen, P. (2016). What Factors Influence Knowledge Sharing in Organizations?: A Social Dilemma Perspective of Social Media Communication. Journal of Knowledge Management, 20(6), 1225-1246.

Simon, H. (1982). A vezetôi döntés új tudománya. Budapest, Statisztikai Kiadó Vállalat.

Szaboszlai, V., Velencei, J., Baracskai, Z. (2014). Post-Experiental Education: from Knowledge to Knowing. Acta Polytechnica Hungarica, 11(10), 235-247.

Szeghegyi, Á. (2011). A tudásmenedzsment stratégiai szerepe a vállalatoknál. In: Nagy Imre Zoltán (Ed.). Vállalkozásfejlesztés a XXI. században: tanulmánykötet. Budapest, Óbudai Egyetem Keleti Károly Gazdasági Kar, 53-68.

Tryon, Jr. C.a. (2012). Managing Organizational Knowledge, 3rd Generation Knowledge Management ... and Beyond. London, CRC Press.

Velencei, J. (2012). E-Coaching Trough Knowledge Platfrom. In: Kadocsa, Gy (Ed.). Proceedings of the 10th International Conference on Management, Enterprise and Benchmarking. Budapest, Óbuda University, 235-242.

Velencei, J., Baracskai, Z. (2016). Knowledge Management Initiatives and Strategies in Small and Medium Enterprises. In: Bencsik, A.(Ed.). Decision Maker in the Global Village: Thinking Together. Hersey, IGI Global, pp. 25-41.

Velencei, J. (2014). Embervezényelt folyamatok: a tudásmegosztók fukarsága. Vállalkozásfejlesztés a XXI. században IV. Tanulmánykötet. Óbudai Egyetem, pp. 337346.

Verzuh, E. (2005). The Fast Forward MBA in Project Management. New Jersey, Hoboken, Wiley \& Sons Inc.

Wang, X. F., Chen, G. (2002). Synchronization in Scale-free Dynamical Networks: Robustness and Fragility. IEEE Transactions on Circuits and Systems I: Fundamental Theory and Applications, 49(1), 54-62.

Wasserman, S., Faust, K. (1994). Social Network Analysis: Methods and Applications. New York, Cambridge University Press.

Watts, D. J., Strogatz, S. H. (1998). Collective Dynamics of Small-world Networks. Nature, $393,440-442$. 